\title{
Phenocopy Alteration
}

National Cancer Institute

\section{Source}

National Cancer Institute. Phenocopy Alteration. NCI Thesaurus. Code C48200.

Observable properties of genetic character, changed or induced by a modification. The resultant progeny inherits physical distinctive traits indicative of the specific parent gene.

The source of alteration can be environmental, or due to internal aberration such as a mutation. 